\title{
Can $\delta^{18} \mathrm{O}$ help indicate the causes of recent lake area expansion on the western Tibetan Plateau? A case study from Aweng Co
}

Yuzhi Zhang, Matthew Jones, Jiawu Zhang, Suzanne McGowan, Sarah Metcalfe

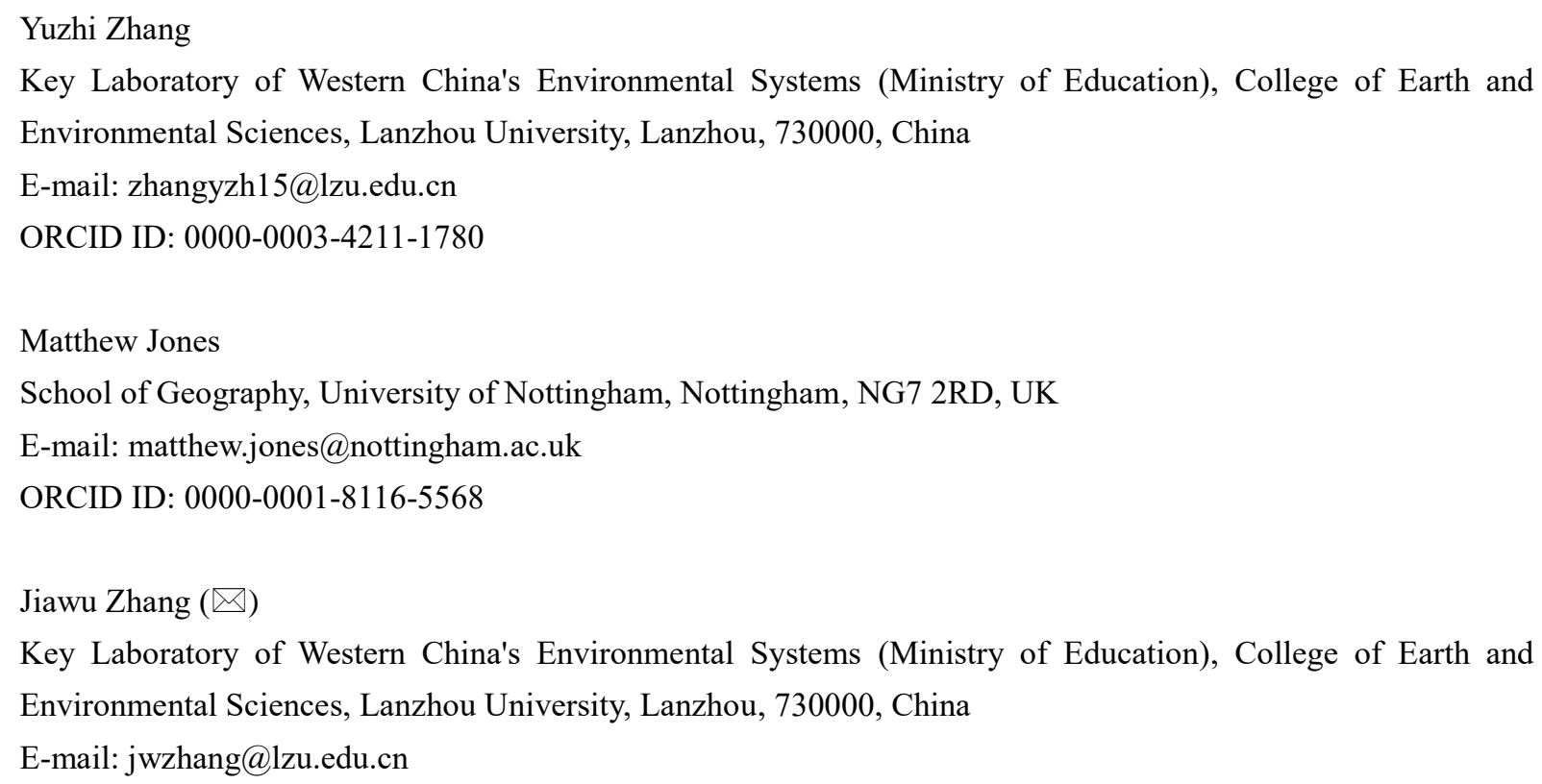

Key words: Lake sediment, Oxygen isotope, Water-balance model, Glacial melt water 
41 Abstract: Glacier-fed lakes on the Tibetan Plateau (TP) have undergone rapid expansions since the late 1990s, concurrent with the changing climate. However, the dominant cause(s) of lake area increases is still debated. To identify the drivers of lake expansion, we studied Aweng Co, a glacier-fed lake in the western TP, where surface area has increased $\left(0.74 \mathrm{~km}^{2} \mathrm{yr}^{-1}\right)$ since the late $1970 \mathrm{~s}$ and most rapidly $\left(0.998 \mathrm{~km}^{2} \mathrm{yr}^{-1}\right)$ since the late $1990 \mathrm{~s}$. A water balance model was used to clarify the reasons for increased lake water volume, supported by stable isotope hydrology and the $\delta^{18} \mathrm{O}$ change recorded in recent sediments. Results showed that glacial melt water probably had the biggest impact on changes in Aweng Co lake level in recent decades, but that precipitation was also an important contributor. Our study shows that $\delta^{18} \mathrm{O}$ of carbonate $\left(\delta^{18} \mathrm{O}_{\text {carb}}\right)$ has great potential for indicating source changes of water supply in such lakes, but there is a need to be cautious when interpreting $\delta^{18} \mathrm{O}_{\text {carb }}$ due to the influence of multiple hydrological factors, which can change in dominance over time.

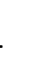

5

6

\section{7} 8 59 60 61 2 63 64 65 


\section{Introduction}

Lake expansion (increased lake surface area) has been identified by remote sensing across the Tibetan Plateau (TP) in recent decades (Crétaux et al. 2016; Lei et al. 2013, 2014, 2017; Song et al. 2014; Zhang et al. 2015, 2017a). New lakes (99 larger than $1 \mathrm{~km}^{2}$ ) have appeared across the TP since 1970 and $81 \%$ of the existing lakes have expanded, with a total increase in surface area of $7240 \mathrm{~km}^{2}$ between the 1970s and 2010 (Zhang et al. 2017a). Most lakes in the inner TP have undergone an apparent increase in area since 1998 (Zhang et al. 2017a), verified both by satellite images and by ICESat altimetry measurements between 2003 and 2009 (Phan et al. 2012; Song et al. 2013). Total water storage in 312 lakes $\left(>10 \mathrm{~km}^{2}\right)$ across the whole TP increased by an estimated 4.3 Gt from the early 1970 s to 2000 and by 88.1 Gt between 2000 and 2011 (Song et al. 2014).

The major factors leading to lake area increases have been identified as increases in runoff generated by more precipitation (Lei et al. 2014; Yang et al. 2014), glacier melt water (Yao et al. 2007, 2012) and permafrost thaw caused by higher temperatures (Yang et al. 2010). However, the impacts of climatic drivers on lake water balance are complex, often interconnected, and variable across the interior TP. Lakes in different regions of the TP are recharged by different sources of water including rainfall, snowfall, glacier melt water and groundwater. In the central, northern, and northeastern TP, lake levels increase during the warm season and decline in the cold season, related to annual changes in monsoonal precipitation and evaporation (Lei et al. 2017). In the northwestern TP, however, lake levels increase both in spring (March to May) and in summer (June to August); this is closely linked to increased snowfall in spring and glacier melt in summer, which currently accounts for 30-40\% of total annual precipitation (Lei et al. 2017).

Water balance models based on meteorological data, are an efficient way to investigate the effects of climate change on hydrological processes for water resource planning (Gleick 1987; Guo et al. 2002; Rouse 1998; Song et al. 2014). These models have been widely used for estimating the relative importance of hydrological sources and sinks (Conway 1997; Xu et al. 2020; Zhu et al. 2010) and predicting conseque nces of future changes in streamflow (Atkinson 
et al. 2002). Such models have, however, only previously been applied to six lakes located in the central TP (Lei et al. 2013; Zhu et al. 2010) where hydrological controls are largely monsoonal-driven. Less is known of hydrological processes in the western TP. Lake sediment records are widely used for studying regional hydrological variations, such as lake level changes (Magny 2004; Qiang et al. 2013; Rowe et al. 2003). Combining water balance models based on instrumental datasets with palaeolimnology is a potentially powerful validation approach for understanding the drivers of lake change.

Given the multiple potential drivers of lake level change, a lake-by-lake rather than a regional conceptual model approach is needed for down core interpretations of hydroclimatic change. Here we present a detailed study of lake area change since the late 1990s from an alpine lake, Aweng Co in the western TP. The lake is hydrologically closed, fed by direct precipitation onto the lake surface, and runoff generated by precipitation and glacier melt water. In order to identify the dominant factors that led to lake area expansion, we analysed the components of a water balance model that could influence lake water volume change since the late 1990s,

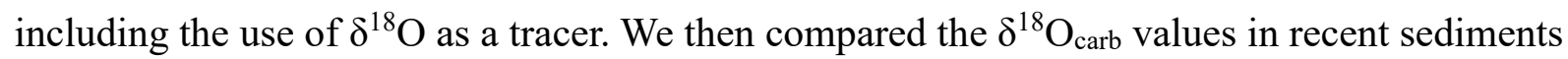
with the water balance model to verify the water supply variations, and to understand the

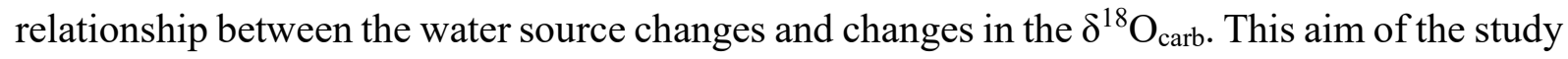
is to improve our understanding of the factors controlling lake system change in such environments, over both recent and palaeo-timeframes.

\section{Study Site}

Aweng Co (A'ong Co, 32.70 $\sim 32.82^{\circ} \mathrm{N}, 81.63^{\circ} \sim 81.80^{\circ} \mathrm{E}$ ) is a closed-basin saline lake located in the western Tibetan Plateau (Fig. 1a). It lies at 4,430 m a.s.1. and is surrounded by $500 \mathrm{~m}$ high hills. Catchment vegetation, where present, is typical of alpine desert steppe including Stipa grasses. The catchment mainly consists of Cretaceous granite and Jurassic metamorphosed sandstone. Aweng Co is an elongated, shallow lake, which is $23.4 \mathrm{~km}$ long with a mean and maximum width of $2.52 \mathrm{~km}$ and $5.30 \mathrm{~km}$ respectively; the maximum water depth is $6 \mathrm{~m}$. Within a large catchment area $\left(2052.30 \mathrm{~km}^{2}\right)$, the current lake water area is only 68.96 
$\mathrm{km}^{2}$ (in 2015). In the western part of the catchment, glaciers and snow at elevations higher than $5000 \mathrm{~m}$ a.s.l (Fig. 1b) cover an area of $125.80 \mathrm{~km}^{2}$ (Li et al. 2017; Song et al. 2014; Wang et al. 1998), and are currently approximately $50 \mathrm{~km}$ from the lake. Satellite imagery shows that the lake area expanded dramatically from the late 1990s (ESM 1).

In 2015 a pH of 9.2 and salinity of $29.5 \mathrm{~g} \mathrm{~L}^{-1}$ were recorded in the lake centre, with concentrations of $1850 \mathrm{mg} \mathrm{L}^{-1} \mathrm{CO}_{3}{ }^{2-}$ and $2023 \mathrm{mg} \mathrm{L}^{-1} \mathrm{HCO}_{3}{ }^{-}$. Meteorological data at the Shiquanhe Station (32.50 $\mathrm{N}, 80.08^{\circ} \mathrm{E}$; altitude: $4279.3 \mathrm{~m}$ a.s.1.), $150 \mathrm{~km}$ from Aweng Co, show that mean annual temperature and total precipitation are $0.68{ }^{\circ} \mathrm{C}$ and $69.11 \mathrm{~mm}$ (for the period 1971-2012, https://data.cma.cn/). $87.6 \%$ of precipitation at Shiquanhe falls between May and September during the Indian Summer Monsoon (ISM) season (Fig. 1c). The mean temperatures in January and July are $-12{ }^{\circ} \mathrm{C}$ and $14{ }^{\circ} \mathrm{C}$, respectively. Monthly mean temperature is above $0{ }^{\circ} \mathrm{C}$ between May and October (Fig. 1c), and the lake surface usually freezes in October and thaws in May. The $\delta^{18} \mathrm{O}$ value of the central lake waters was $0.2 \%$ in 2015.

\section{Materials and Methods}

Lake volume reconstruction

The region has been monitored by satellite imagery since the 1970 s, including Landsat $4-5$ Thermal Mapper (TM), Landsat 7 Enhanced Thematic Mapper (ETM), and Landsat 8 Operational Land Imager (OLI). Lake area data from the National Tibetan Plateau Data Center (http://data.tpdc.ac.cn; Zhang et al. 2014, 2019a; Zhang 2019) is averaged over 3 or 4 years, and so is of insufficient resolution to determine annual changes in lake area. Therefore, we used images with no cloud cover from the Geospatial Data Cloud (http://www.gscloud.cn/; ESM 2), sampled at a consistent time of the year (September - October) to minimize the influence of seasonal variability (Zhang et al. 2017b). This period is useful for comparing inter-annual changes in lake area because it records lake size at the end of the warm and wet season. Gaps in the Landsat ETM+ scan line corrector-off images were filled by the neighbourhood similar pixel interpolator algorithm (Chen et al. 2011). Lake area data before 1990 was downloaded 
from the National Tibetan Plateau Data Center (Zhang et al. 2014, 2019a; Zhang 2019).

We calculated past changes in lake volume using a combination of the lake area measurements and a digital elevation model (DEM) of the lake, derived from a bathymetric survey by SM-5A hand-held sonar conducted in 2015. Lake volume was calculated using the VOLUME function in Surfer 11.0 sequentially lowering lake levels. Lake level altitude data was derived from ICEsat Laser altimetry measurements, which were available from 2003 to 2009 (Zhang et al. 2011, 2017a). We calculated the lake level altitude for 1999 2002 and 2015 and thereby lake volume, according to the correlation between lake area and lake-level altitude from 2003 to 2009. The lake volume before 1999 was calculated from this relationship using lake area measurements from the National Tibetan Plateau Data Center (Zhang et al. 2014, 2019a; Zhang 2019).

Stable isotopes of water and sediments

In 2015, a $411.5 \mathrm{~cm}$ long sediment core (AWC2015B) was taken from the central part of the lake $\left(32.75^{\circ} \mathrm{N}, 81.76^{\circ} \mathrm{E}\right)$ at a water depth of $6 \mathrm{~m}$ using a UWITEC corer (Fig. 1b). The chronology of the core top was established by ${ }^{137} \mathrm{Cs}$ and ${ }^{210} \mathrm{~Pb}$ using HPGe Gamma Spectrometry. ${ }^{210} \mathrm{~Pb}$ was obtained via gamma-emission at $46.5 \mathrm{keV}$ and ${ }^{226} \mathrm{Ra}$ at $351.92 \mathrm{keV} \gamma$ rays emitted by its daughter isotope ${ }^{214} \mathrm{~Pb}$. The age of the top sediment was established by the Constant Rate of Supply (CRS) model (Appleby and Oldfield 1978). The top $14 \mathrm{~cm}$, which covered the period with instrumental data, was used in this study, with a sampling interval of $0.5 \mathrm{~cm}$.

Fine-grained carbonates $(<40 \mu \mathrm{m}$ fraction) were collected from sediments by wet sieving and then dried at $50{ }^{\circ} \mathrm{C}$ for 6 hours. The minerogenic composition was confirmed to be aragonite by X-ray diffraction analysis. Stable oxygen isotopes were analysed from the carbonates using a ThermoFisher MAT 253 mass spectrometer with an automated carbonate preparation device (Kiel IV). Four standards (NBS18, NBS19, GBW04406, GBW04405) were measured every 10 samples. Analytical precision for $\delta^{18} \mathrm{O}$ and $\delta^{13} \mathrm{C}$ was better than $0.1 \%$. Values were reported relative to the Vienna Pee Dee Belemnite (VPDB) standard. All the 
measurements were carried out in the Key Laboratory of Western China's Environmental Systems, Lanzhou University.

During the field season (in July 2015) a number of lake water and precipitation samples were taken from the lake and catchment to better understand the isotope hydrology of the lake system. Lake water and a groundwater sample from a catchment spring were filtered using a syringe filter with $0.45-\mu \mathrm{m}$ membranes and then hermetically stored in a $5 \mathrm{~mL}$ polyethylene bottle. Rainfall samples were also collected and sealed in a $5 \mathrm{~mL}$ polyethylene bottle. Falling snow was collected in a clean stainless steel bowl, which melted quickly as it was at the end of June, and the resulting water was then transferred into a $5 \mathrm{~mL}$ polyethylene bottle. All the water samples were stored at $4{ }^{\circ} \mathrm{C}$ before analysis. Stable isotopes of all the samples were measured by an Isotopic Liquid Water Analyzer (Picarro L1102-i) at Lanzhou University. The values are reported relative to the Vienna Standard Mean Ocean Water (VSMOW) standard. Analytical precision for $\delta^{18} \mathrm{O}$ and $\delta^{2} \mathrm{H}$ was better than $0.1 \%$ and $0.3 \%$, respectively.

Hydrological model

To begin to identify the likely contributions of hydroclimate, such as evaporation, precipitation, and glacial melt water, to the observed increase in Aweng Co lake area over recent decades, we attempted to model the lake hydrology based on equation 1 . We made the assumption that volume changes at Aweng Co are controlled by a number of inputs and outputs to the system (Equation 1), recognising that there is no surface outflow from the lake.

$\Delta V_{L}=P_{L} S_{L}+R_{C} S_{C}+G M W+G_{I}-E_{L} S_{L}-G_{O}$ where $\Delta V_{L}$ is the change in lake volume $\left(\mathrm{m}^{3}\right)$ in a given time, $P_{L}$ is the precipitation onto the lake surface, $S_{L}$ is the lake surface area; $R_{C}$ is runoff from the catchment; $S_{C}$ is the catchment area excluding the lake area; $E_{L}$ is the total evaporation on the lake surface; $G M W$ is the glacier melt water and $G_{I}$ and $G_{O}$ are inflow and outflow groundwater components respectively. Because the lake area of Aweng Co expanded dramatically since the late 1990s, we employed the water balance model for the period of 1999-2009 in this study.

$\Delta V_{L}$, the change in lake volume, is a known value, as are the lake and catchment areas 
from the remote sensing work. Because there is no meteorological station in the study area, precipitation in the Aweng Co basin was taken from the LZU0025 dataset (Wu et al. 2014) calculated using the Thin Plate Smoothing Spline (TPSS) method which interpolates data from all meteorological stations in China. Due to the positive correlation between precipitation and elevation in the western Tibetan Plateau (Zhang et al. 2019b), the interpolated precipitation values in the Aweng Co catchment (Table 1) are higher than those from Shiquanhe Station. The quantity of the precipitation falling on the catchment that reaches the lake is unknown, and is probably a combination of surface and groundwater, or at least sub-surface flow. Here we take overland flow $\left(R_{c}\right)$ to be a proportion $(c)$ of precipitation falling on the catchment.

Glacial melt water may reach the lake through both overland and sub-surface flow. Here $G M W$ is taken to be the surface component, such that $G M W$ is estimated based on the measured change in glacial volume available for the Aweng Co catchment, multiplied by a constant $(g)$. To convert measured glacial area $\left(S_{g}\right)$ to a volume $\left(V_{g}\right)$ we used the formula from Zhu et al. (2010) based on data from 253 glaciers in the China Glaciers Catalogue, $V_{g}=0.042 S_{g}^{1.3565}$. Variation in glacier volume was converted to glacier melt water volume by multiplying by 0.85 (Huss 2013), and only $42 \%$ of this volume is known to drain into the Aweng Co basin (Neckel et al. 2014). Unknown constants $c$ and $g$ both therefore take into account potential infiltration and evapotranspiration, i.e. factors that prevent all precipitation or melt water flowing directly into the lake.

$E_{L}\left(\mathrm{~mm} \mathrm{day}^{-1}\right)$ is calculated using the equation of Linacre (1992) such that

$E_{L}=\left[0.015+4 \times 10^{-4} T_{a}+10^{-6} z\right] \times\left[480 \frac{\left(T_{a}+0.006 z\right)}{84-A}-40+2.3 u\left(T_{a}-T_{d}\right)\right]$

where $T_{a}$ is air temperature $\left({ }^{\circ} \mathrm{C}\right), z=$ altitude $(\mathrm{m}), A=$ latitude (degrees), $u=$ wind speed (m $\left.\mathrm{s}^{-1}\right), T_{d}=$ dew point temperature $=0.52 T_{a \text { min }}+0.60 T_{a \text { max }}-0.009\left(T_{a \max }\right)^{2}-2{ }^{\circ} \mathrm{C}$. This has been shown to be a reasonable estimate of evaporation where full suites of meteorological data are not available (Jones et al. 2016). Because data for $T_{a \text { min }}, T_{a \text { max }}$ and $u$ are unavailable in the LZU0025 dataset, they were taken from the National Centers for Environmental Prediction (NCEP)-Department of Energy (DOE) Reanalysis 2 Gaussian Grid data (https://www.esrl.noaa.gov/psd/data/gridded/data.ncep.reanalysis2.gaussian.html). When calculating the precipitation and evaporation on the lake surface, we used the mean lake area 
for the measurement year, estimated from the lake area at the beginning and end of each year. $G_{i}$ and $G_{o}$ are unknown.

To investigate the remaining unknowns in the lake hydrology model we firstly aimed to optimize calculated changes in lake volume, using equation 1, with those that have been measured. As a first order test, we aimed to optimize values of $c$ and $g$ such that these constants are $\geq 0$ and the regression relationship between known and modelled $\Delta V_{L}$ has a slope and $r^{2}$ of 1 and an intercept of 0 .

We then took an index lake approach (Gibson et al. 2016; Jones et al. 2016) to understand whether the lake is likely to have any groundwater outflow. This approach calculates the isotopic composition of the theoretical lake $\left(\delta_{L}\right)$ that sits at the extreme end of the local evaporation line (LEL) i.e. a fully closed hydrological system where $P \delta_{P}=E \delta_{E}$. As $\delta_{E}$ is a function of $\delta_{L}$, and in the case of the index lake $\delta_{E}=\delta_{P}, \delta_{L}$ can be calculated. We use the $\delta_{E}$ equation based on the Craig-Gordon Evaporation model (Craig and Gordon 1965), as used by Steinman et al. (2010a, b):

$\delta_{E}=\frac{\alpha^{*} \delta_{L}-h \delta_{A^{-}-\varepsilon}}{1-h+0.001 \varepsilon_{k}}$

where $\alpha^{*}$ is the equilibrium isotopic fractionation factor dependent on the temperature at the evaporating surface. For oxygen

$\frac{1}{\alpha^{*}}=\exp \left(1137 T_{L}^{-2}-0.4256 T_{L}^{-1}-2.0667 \times 10^{-3}\right)$

and for hydrogen

$\frac{1}{\alpha^{*}}=\exp \left(24844 T_{L}^{-2}-76.248 T_{L}^{-1}-52.61 \times 10^{-3}\right)$

Where $T_{L}$ is the temperature of the lake surface water in degrees Kelvin (Majoube 1971), $h$ is the relative humidity normalized to the saturation vapour pressure at the temperature of the air water interface and $\varepsilon_{k}$ is the kinetic fraction factor; for $\delta^{18} \mathrm{O}, \varepsilon_{k}$ has been shown to approximate 14.2(1-h) and 12.5 $(1-h)$ for $\delta^{2} \mathrm{H}$ (Gonfiantini 1986). $\delta_{A}$ is the isotopic value of the air vapour over the lake and $\varepsilon=\varepsilon^{*}+\varepsilon_{k}$ where $\varepsilon^{*}=1000\left(1-\alpha^{*}\right)$.

Gibson (2002) and Gibson et al. (2016) have shown that the relationship between $\delta_{P}$ and $\delta_{A}$ varies in different environmental settings, and advocate using a measured LEL, as we have available here, to calculate the suitable regional $\delta_{P}-\delta_{A}$ relationship. 
Finally, we attempted to balance the hydrological and isotopic components of the Aweng

Co lake system, to give estimates for each of the parameters in equation 1. Based on optimized values of $c$ and $g$, and a constant groundwater inflow, and using average values for each modelled component from the 10 years of monitoring for which lake volumes were measured (Table 1, ESM 3) we undertook a mass balancing exercise, such that lake inputs should balance lake outputs (Lacey and Jones 2018), i.e.

$P_{L} \delta_{P L}+R_{i} \delta_{\mathrm{R} i}+G M W \delta_{G}+G_{i} \delta_{G i}=E \delta_{E}+G_{o} \delta_{L}$

As all isotopic values are known, equation 6 can then be optimized, varying groundwater inputs such that the equation balances for both $\delta^{18} \mathrm{O}$ and $\delta^{2} \mathrm{H}$ values, resulting in estimates for the percentage contribution of each of these parameters to the Aweng Co hydrology.

\section{Results}

Changes in lake volume since the late 1990s

Between 1980 and 1999, lake area and lake volume of Aweng Co increased from $46.51 \mathrm{~km}^{2}$ to $60.69 \mathrm{~km}^{2}$ and from $57.52 \times 10^{6} \mathrm{~m}^{3}$ to $83.74 \times 10^{6} \mathrm{~m}^{3}$, respectively; with a rapid lake area expansion between $1996 \sim 1999$ (Fig. 2d). Before 1999, lake area and lake volume increased slowly at $0.74 \mathrm{~km}^{2} \mathrm{yr}^{-1}$ and $1.38 \times 10^{6} \mathrm{~m}^{3} \mathrm{yr}^{-1}$, respectively. After 1999 lake area and lake volume increased reaching $69.15 \mathrm{~km}^{2}$ and $125.02 \times 10^{6} \mathrm{~m}^{3}$ in 2002, and then decreased until 2005; with an increase from 2006, culminating in 2008 with an area of $71.06 \mathrm{~km}^{2}$ and a volume of $136.77 \times 10^{6} \mathrm{~m}^{3}$, respectively. The lake reached maximum size for the study period in 2010 with an area of $71.67 \mathrm{~km}^{2}$ and a volume of $153 \times 10^{6} \mathrm{~m}^{3}$, and then shrank a little (Fig. 2d, 2e). The lake area and lake volume increased at a rate of $0.998 \mathrm{~km}^{2} \mathrm{yr}^{-1}$ and $6.29 \times 10^{6} \mathrm{~m}^{3} \mathrm{yr}^{-1}$ from 1999 to 2010.

Correlations (Fig. 3) between each known hydroclimate parameter and lake volume change show that precipitation and glacier melt water changes both have significant and positive correlations with lake volume change. Evaporation has a negative relationship with 
lake volume change, but the relationship is relatively weak, and not significant.

\section{Aweng Co Isotope Hydrology}

Precipitation samples at Aweng Co (Fig. 4) lie on a local meteoric water line (MWL). Lake water samples lie to the right of the Aweng Co MWL, and with the groundwater sample describe a local evaporation line (LEL) with a gradient of 5.64 (Fig. 4).

\section{Model Results}

The results of initial optimization showed it is difficult to optimize $r^{2}$, slope and intercept concurrently (Table 2), and the best combination of $c, g$ and groundwater input, to give variability in the model at a magnitude that matches the measured volume changes is where $c$ and $g$ are optimized to give a regression with slope of 1 (resulting in an $r^{2}$ of 0.64) in which case a constant amount of groundwater inflow supplying the lake is required to give the 0 intercept.

When calculating $\delta_{L}$ for the "index lake" we used a lake system where $\delta_{E}$ was equal to the intercept value of the LEL and Aweng Co MWL. In this case for $\delta_{L}, \delta_{A}$ and $\delta_{E}$ to sit sensibly in $\delta^{18} \mathrm{O}-\delta \mathrm{D}$ space (Fig. 4 ), an adjustment, via a constant $(k$ ), is required to the standard equilibrium relationship between $\delta_{P}$ and $\delta_{A}$ (Gibson et al. 2016), where:

$\delta_{A}=\frac{\delta_{P}-k \varepsilon^{*}}{1+10^{-3} \cdot k \varepsilon^{*}}$

The value of $k$ needed here (0.5), to fit the theoretical LEL to that measured in this study is typical for highly seasonal climates such as that at Aweng Co (Gibson et al. 2016).

The contributions of each component from the balanced $\delta^{18} \mathrm{O}$ and $\delta^{2} \mathrm{H}$ isotopic models (equation 6) are nearly the same (Table 3). Based on the $\delta^{18} \mathrm{O}$ balance model, the biggest supplier of water to Aweng Co is groundwater inflow, which accounts for $67 \%$ and the smallest is glacier melt water that is $4 \%$. Precipitation and runoff in the catchment supply $10 \%$ and $19 \%$ to the hydrological systems, respectively. Evaporation accounts for $57 \%$ of the water loss, more than the groundwater outflow, which is $43 \%$. 
Sediment chronology and proxies

The dating model for the top of the core showed that the sediments at $14 \mathrm{~cm}$ depth were deposited ca. 1898 AD (ESM 4). We used the upper $7 \mathrm{~cm}$ of sediment in this study, which represented the time period since the late $1970 \mathrm{~s}$, with a sampling resolution of $0.5 \mathrm{~cm}(2.6$ years). The $\delta^{18} \mathrm{O}_{\text {carb }}$ values were around $1.5 \%$ between 1979 and 1984, and then decreased to $0.34 \%$ in 1989 and kept relatively stable until 1997, followed by a trough (with a lowest $\delta^{18} \mathrm{O}_{\text {carb value of }}-1.24 \%$ ) around the mid-2000s and a positive trend after $\sim 2007$ (Fig. $2 \mathrm{~g}$ ).

Discussion

Contributors to lake volume change: monitoring and modelling results

The combined monitoring and various modelling exercises for Aweng Co presented here have, at least on a general scale, begun to tell a coherent story for the lake system. The combined hydrological and isotope mass balance modelling (Table 3) give a similar picture to the waterisotope bi-plot (Fig. 4) in suggesting that both evaporation and groundwater are important outputs from the lake. The estimate of two thirds loss by evaporation (Table 3 ) is a sensible order of magnitude given the location of Aweng Co on the LEL (Fig. 4), the gradient of which is very similar to the LEL gradient (5.51) for other closed lakes that have experienced lakeexpansions in recent decades on the Tibetan Plateau (Yuan et al. 2011). Correlations (Fig. 3) between each known hydroclimate parameter and lake volume change indicate both glacial melt water and changing precipitation amount could be controlling the observed lake area change.

To further refine our hydrological model we used the isotope hydrology of the site (Fig. 4). Groundwater, isotopically, lies on the Aweng Co MWL, which has a similar gradient to the MWL described by Guo et al. (2017) for Ngari, $190 \mathrm{~km}$ far from Aweng Co and $\sim 170 \mathrm{~m}$ lower. If the groundwater is a mixture of both precipitation and glacial melt water, the isotope values of these different components could help to estimate the relative contributions of the two 
sources. There are minimal data with which to undertake this exercise, but with that available we can make a preliminary estimate of the amount of precipitation and glacier melt water in the groundwater entering Aweng Co. The most negative of the precipitation samples collected in the 2015 field season $\left(\delta^{18} \mathrm{O}=-13.86 \% ; \delta^{2} \mathrm{H}=-115.48 \%\right.$ ) was a sample of snow, and therefore probably lies towards the negative isotopic end of local precipitation. There are no isotope data from the glacier that feeds Aweng $\mathrm{Co}$, but $\delta^{18} \mathrm{O}$ values for other Tibetan glaciers are typically in the range of the catchment's snow sample. The average $\delta^{18} \mathrm{O}$ value from the Puruogangri Ice Cap is $-13.66 \%$ in the most recent 50 years (Thompson et al. 2011), the upper meters of the Guliya Ice Cap, in the north of the plateau, and in a different climate region to Aweng Co, average $-11.2 \%$ and $-13.1 \%$ from the 2015 and 1992 cores respectively (Thompson et al. 2018). Given these values, and the groundwater sample $\left(\delta^{18} \mathrm{O}=-12.29 \%\right.$, $\delta^{2} \mathrm{H}=-99.77 \%$ ), it appears likely that this groundwater is dominated in composition by snow and glacier melt water $(\sim 70 \%)$, although distinguishing between these two would need further monitoring of the Aweng Co system. It is also possible that our precipitation values and runoff constant underestimate the amount of snowmelt that enters the lake, such that our "groundwater" value here includes all currently unmeasured inflows, including snow melt.

For the differing inflow parameters, given the location of the groundwater sample and average precipitation in $\delta^{18} \mathrm{O} \delta^{2} \mathrm{H}$ space (Fig. 4), if $\sim 70 \%$ of the "groundwater" inflow comes from ice and snow melt, then approximately $50 \%$ of Aweng Co inflow (surface and groundwater) comes from ice and snowmelt and $50 \%$ from summer rainfall. This would suggest that for this lake system both glacier melt and rainfall changes may help to explain recent lake area expansion.

One potential way to distinguish further which component may have been more significant in recent times is to look at the potential sensitivity of the system to changes in these different parameters. Although there is a strong correlation between precipitation and lake volume change (Fig. 3) the magnitude of lake area and lake volume change through the time period of this correlation (1999-2009) is small compared to the longer term variability (Fig. 2). Over the longer period since $\sim 1980$ there have been larger increases in lake area, but no similar trend in increasing annual precipitation. 

glacier area, as a proxy for melt water, through the 1999-2009 window, but the significant decline in glacier area between 1997 and 1999 matches the significant period of lake area expansion which, alongside the lack of significant shifts in precipitation trends through that time period, suggests that it was glacier melt water which drove the change in lake volume.

The analyses presented here suggest that isotope hydrology can help further the understanding of controls on changes in western Tibetan lakes, but that to fully exploit their potential a more detailed monitoring programme needs to be undertaken, ideally over a number of years.

$\delta^{18} \mathrm{O}_{\text {carb }}$ evidence

The variation of $\delta^{18} \mathrm{O}_{\text {carb }}$ is controlled by lake water $\delta^{18} \mathrm{O}$ and temperature changes (Leng and Marshall 2004; Xu et al. 2006), and therefore the signals of lake hydrology variations could be preserved in the $\delta^{18} \mathrm{O}_{\text {carb }}$ sediment record. The mean summer temperature change rise of $1.1^{\circ} \mathrm{C}$ (Fig. 2b) would lead to $\delta^{18} \mathrm{O}_{\text {carb }}$ change of $\sim 0.26 \%$ based on a temperature-dependence of carbonate fractionation of $-0.24 \% /{ }^{\circ} \mathrm{C}$ (Craig 1965), which is not enough to explain the

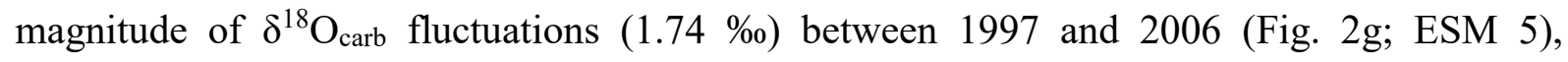
suggesting that changes in lake water $\delta^{18} \mathrm{O}$ have been important in driving the recorded $\delta^{18} \mathrm{O}_{\text {carb }}$. This, alongside the importance of evaporation in the lake system (Fig. 4) suggests that the inflow to evaporation ratio (I:E) is probably the main driver of $\delta^{18} \mathrm{O}_{\text {carb }}$ at Aweng Co. Of particular interest through recent decades is the negative excursion in $\delta^{18} \mathrm{O}_{\text {carb }}$ between $\sim 1999$ and 2008 , which would need an increase in inflow or decrease in evaporation in an I:E driven system, or a significant change in the isotopic component of the inflowing water.

During the period 1999 to 2007, evaporation at the lake surface showed an overall slight increasing trend (Fig. 2c), with only a short, two year, reduction in evaporation through that time. Even within the chronological uncertainties of the core record, this is not enough to explain the trends in the $\delta^{18} \mathrm{O}_{\text {carb }}$ record.

Comparison of trends in precipitation (Fig. 2a) with the $\delta^{18} \mathrm{O}_{\text {carb }}$ record also shows no 
clear relationship between periods of increased amounts of precipitation and negative isotope excursions. The biggest decline in glacier area in the late 1990s does match, within the chronological errors of the core, the $\delta^{18} \mathrm{O}_{\text {carb }}$ shift to more negative values (-1.24 \%o in 2006). Given I:E ratio is likely the main driver of $\delta^{18} \mathrm{O}_{\text {carb }}$ change, an increased amount of glacier melt water would increase lake area/volume and lead to a negative shift in $\delta^{18} \mathrm{O}_{\text {carb. }}$

Although the $\delta^{18} \mathrm{O}_{\text {carb }}$ returns to early 1990 s values $(\sim 0.5 \%$ ) after the negative excursion towards the top of the core (Fig. 2), there are no similar returns for either the glacier area or the lake area. One interpretation for the difference is that the lake isotope values are returning to a steady state following the negative excursion, but these isotope values are similar to those when the lake level was lower. This could be because inflows and outflows to the system are generally the same in both the low and high lake level status. In such a system, flux, which has been considered important in controlling $\delta^{18} \mathrm{O}_{\text {carb }}$ in other lake systems (Jones et al. 2007), remains the same, while volume has increased due to the elevated glacial melt water period in the late 1990s. In this scenario it is also possible that the negative excursion under discussion is a result of the particularly negative isotopic value of that glacial melt water, rather than the amount of it, such that the impact of this input changed the $\delta^{18} \mathrm{O}_{\text {carb }}$ record more than the volume change. Meanwhile, the duration of the isotopic impact was limited by the relatively short residence time of the water, with negative isotopic water flushed through the system, whilst lake volume remains relatively unchanged. Overall, it is likely that a combined effect of increased inflow of particularly isotopically-negative glacial melt water led to this negative shift in $\delta^{18} \mathrm{O}_{\text {carb }}$.

This comparison exercise shows how even with instrumental data available for contrast, the interpretation of $\delta^{18} \mathrm{O}_{\text {carb }}$ records is complicated by the multiple potential controls that can lead to an abrupt change in a core $\delta^{18} \mathrm{O}_{\text {carb }}$ record. This highlights the need to have multiple proxies from which more robust interpretations of environmental changes from down-core data can be made beyond the instrumental time period.

$\delta \mathrm{D}$

\section{Conclusions}


The combined monitoring, modelling and palaeolimnological approach taken here shows the potential for $\delta^{18} \mathrm{O}_{\text {carb }}$ to be used to investigate lake area change in the western Tibetan Plateau, whilst highlighting the complexities of the system. This understanding is important for using such core records to reconstruct longer term environmental change in the region. Both the monitoring, modelling and $\delta^{18} \mathrm{O}_{\text {carb }}$ evidence point to the importance of glacial melt water in influencing the lake area and isotopic record of Aweng Co, but highlight that the sensitivities of these two parts of the lake system to glacial melt water change can be different. The flux of water through the lake system, controlled by precipitation amount and evaporation as well as glacial melt water, is also therefore important in driving the resulting $\delta^{18} \mathrm{O}_{\text {carb }}$ record preserved in the sediments, and the dominant hydrological controls may change through time.

\section{Acknowledgments}

This study is supported by the National Natural Science Foundation of China (NSFC 41771212) and Fundamental Research Fund for the Central Universities (lzujbky-2017-it81). We would like to thank Juzhi Hou, Mingda Wang, Yaping Yang and Erlei Zhu for assisting the field work. We also thank Melanie Leng for her constructive suggestions in improving the quality of the manuscript, and Xian Wu for providing the interpolated meteorological data in the catchment. We thank Thomas J. Whitmore, Steffen Mischke and two anonymous reviewers for detailed comments which improved the manuscript. The authors have no conflict of interest to declare.

\section{References}

Appleby PG, Oldfield F (1978) The calculation of lead-210 dates assuming a constant rate of supply of unsupported ${ }^{210} \mathrm{~Pb}$ to the sediment. Catena $5: 1-8$

Atkinson SE, Woods RA, Sivapalan M (2002) Climate and landscape controls on water balance model complexity over changing timescales. Water Resour Res 38:50-1-50-15

Chen J, Zhu X, Vogelmann JE, Gao F, Jin S (2011) A simple and effective method for filling gaps in Landsat ETM

+ SLC-off images. Remote Sens Environ 115:1053-1064

Conway D (1997) A water balance model of the Upper Blue Nile in Ethiopia. Hydrol Sci J 42:165-286

Craig H (1965) The measurement of oxygen isotope palaeotemperatures. In: Tongiorgi E (ed) Stable isotopes in oceanographic studies and palaeotemperatures. Consiglio Nazionale delle Ricerche Laboratorio di Geologia Nucleare, Pisa, pp 161-182

Craig H, Gordon LI (1965) Deuterium and oxygen-18 variation in the ocean and marine atmosphere. In: Tongiorgi 
E (ed) Stable isotopes in oceanography studies and paleotemperatures. Consiglio Nazionale delle Ricerche Laboratorio di Geologia Nucleare, Pisa, pp 9-130

Crétaux JF, Abarca-del-Río R, Bergé-Nguyen M, Arsen A, Drolon V, Clos G, Maisongrande P (2016) Lake volume monitoring from space. Surv Geophys 37:269-305

Gibson J (2002) A new conceptual model for predicting isotopic enrichment of lakes in seasonal climates. Pages News 10:10-11

Gibson JJ, Birks SJ, Yi Y (2016) Stable isotope mass balance of lakes: a contemporary perspective. Quat Sci Rev 131:316-328

Gleick PH (1987) The development and testing of a water balance model for climate impact assessment: modeling the Sacramento Basin. Water Resour Res 23:1049-1061

Gonfiantini R (1986) Environmental isotopes in lake studies. In: Fritz P, Fontes J C (eds) Handbook of Environmental Isotope Geochemistry. vol 3. Elsevier Scientific Publishing Company, Amsterdam, pp 113168

Guo S, Wang J, Xiong L, Ying A, Li D (2002) A macro-scale and semi-distributed monthly water balance model to predict climate change impacts in China. J Hydrol 268:1-15

Guo X, Tian L, Wen R, Yu W, Qu D (2017) Controls of precipitation $\delta^{18}$ O on the northwestern Tibetan Plateau: A case study at Ngari station. Atmos Res 189:141-151

Huss M (2013) Density assumptions for converting geodetic glacier volume change to mass change. The Cryosphere, 7(3):877-887

Jones MD, Cuthbert MO, Leng MJ, McGowan S, Mariethoz G, Arrowsmith C, Sloane HJ, Humphrey KK, Cross I (2016) Comparisons of observed and modelled lake $\delta^{18} \mathrm{O}$ variability. Quat Sci Rev 131:329-340

Jones MD, Roberts CN, Leng MJ (2007) Quantifying climatic change through the last glacial-interglacial transition based on lake isotope palaeohydrology from central Turkey. Quat Res 67:463-473

Lacey JH, Jones MD (2018) Quantitative reconstruction of early Holocene and last glacial climate on the Balkan Peninsula using coupled hydrological and isotope mass balance modelling. Quat Sci Rev 202:109-121

Lei Y, Yang K, Wang B, Sheng Y, Bird BW, Zhang G, Tian L (2014) Response of inland lake dynamics over the Tibetan Plateau to climate change. Clim Change 125:281-290

Lei Y, Yao T, Bird BW, Yang K, Zhai J, Sheng Y (2013) Coherent lake growth on the central Tibetan Plateau since the 1970s: Characterization and attribution. J Hydrol 483:61-67

Lei Y, Yao T, Yang K, Sheng Y, Kleinherenbrink M, Yi S, Bird BW, Zhang X, Zhu L, Zhang G (2017) Lake seasonality across the Tibetan Plateau and their varying relationship with regional mass changes and local hydrology. Geophys Res Lett 44:892-900

Leng MJ, Marshall JD (2004) Palaeoclimate interpretation of stable isotope data from lake sediment archives. Quat Sci Rev 23:811-831

Li X, Wang M, Zhang Y, Lei L, Hou J (2017) Holocene climatic and environmental change on the western Tibetan Plateau revealed by glycerol dialkyl glycerol tetraethers and leaf wax deuterium-to-hydrogen ratios at Aweng Co. Quat Res 87:455-467

Linacre E (1992) Climate data and resources: a reference and guide. Routledge, London, pp 366

Magny M (2004) Holocene climate variability as reflected by mid-European lake-level fluctuations and its probable impact on prehistoric human settlements. Quat Int 113:65-79

Majoube F (1971) Fractionnement en oxygene-18 et en deuterium entre l'eau et sa vapeur. J Chem Phys 68: 14231436

Neckel N, Kropáček J, Bolch T, Hochschild V (2014) Glacier mass changes on the Tibetan Plateau 2003-2009 derived from ICESat laser altimetry measurements. Environ Res Lett 9:1-7 
Phan VH, Lindenbergh R, Menenti M (2012) ICESat derived elevation changes of Tibetan lakes between 2003 and 2009. Int J Appl Earth Obs Geoinf 17:12-22

Qiang M, Song L, Chen F, Li M, Liu X, Wang Q (2013) A 16-ka lake-level record inferred from macrofossils in a sediment core from Genggahai Lake, northeastern Qinghai-Tibetan Plateau (China). J Paleolimnol 49:575590

Rouse WR (1998) A water balance model for subarctic sedge fen and its application to climatic change. Clim Change 38: 207-234

Rowe HD, Guilderson TP, Dunbar RB, Southon JR, Seltzer GO, Mucciarone DA, Fritz SC, Baker PA (2003) Late Quaternary lake-level changes constrained by radiocarbon and stable isotope studies on sediment cores from Lake Titicaca, South America. Glob Planet Change 38:273-290

Song C, Huang B, Richards K, Ke L, Phan VH (2014) Accelerated lake expansion on the Tibetan Plateau in the 2000s: Induced by glacial melting or other processes? Water Resour Res 50:3170-3186

Song C, Huang B, Ke L (2013) Modeling and analysis of lake water storage changes on the Tibetan Plateau using multi-mission satellite data. Remote Sens Environ 135:25-35

Steinman BA, Rosenmeier MF, Abbott MB (2010a) The isotopic and hydrologic response of small, closed-basin lakes to climate forcing from predictive models: Simulations of stochastic and mean-state precipitation variations. Limnol Oceanogr 55:2246-2261

Steinman BA, Rosenmeier MF, Abbott MB, Bain DJ (2010b) The isotopic and hydrologic response of small, closed-basin lakes to climate forcing from predictive models: Application to paleoclimate studies in the upper Columbia River basin. Limnol Oceanogr 55:2231-2245

Thompson LG, Mosley-Thompson E, Davis ME, Brecher HH (2011) Tropical glaciers, recorders and indicators of climate change, are disappearing globally. Ann Glaciol 52:23-34

Thompson LG, Yao T, Davis ME, Mosley-Thompson E, Wu G, Porter SE, Xu B, Lin PN, Wang N, Beauson E, Duan K, Sierra-Hernandez MR, Kenny DV (2018) Ice core records of climate variability on the Third Pole with emphasis on the Guliya ice cap, western Kunlun Mountains. Quat Sci Rev 188:1-14

Wang S, Dou H (1998) Records of lakes in China (in Chinese). Science Press, Beijing

Wu X, Huang W, Chen F (2014) Construction and application of monthly air temperature and precipitation gridded datasets with high resolution $(0.025 * 0.025)$ over China during 1951-2012 (in Chinese). J Lanzhou University 50:213-220

$\mathrm{Xu} \mathrm{H}$, Ai L, Tan L, An Z (2006) Stable isotopes in bulk carbonates and organic matter in recent sediments of Lake Qinghai and their climatic implications. Chem Geol 235:262-275

Xu H, Goldsmith Y, Lan J, Tan L, Wang X, Zhou X, Cheng J, Lang Y, Liu C (2020) Juxtaposition of western Pacific subtropical high on Asian summer monsoon shapes subtropical East Asian precipitation. Geophys Res Lett 47:1-10

Yang K, Wu H, Qin J, Lin C, Tang W, Chen Y (2014) Recent climate changes over the Tibetan Plateau and their impacts on energy and water cycle: A review. Glob Planet Change 112:79-91

Yang M, Nelson FE, Shiklomanov NI, Guo D, Wan G (2010) Permafrost degradation and its environmental effects on the Tibetan Plateau: A review of recent research. Earth Sci Rev 103:31-44

Yao T, Pu J, Lu A, Wang Y, Yu W (2007) Recent glacial retreat and its impact on hydrological processes on the Tibetan Plateau, China, and surrounding regions. Arctic Antarct Alp Res 39:642-650

Yao T, Thompson L, Yang W, Yu W, Gao Y, Guo X, Yang X, Duan, K, Zhao, H, Xu B, Pu J, Lu A, Xiang Y, Kattel DB, Joswiak D (2012) Different glacier status with atmospheric circulations in Tibetan Plateau and surroundings. Nat Clim Change 2:663-667

Yuan F, Sheng Y, Yao T, Fan C, Li J, Zhao H, Lei Y (2011) Evaporative enrichment of oxygen-18 and deuterium 

J Remote Sens 38:742-772

Zhang Y, Li Y, Zhu G (2019b) The effect of altitude on temperature, precipitation and climatic zone in the QinghaiTibetan (in Chinese). J Glaciol Geocryol 41:505-515

Zhang G, Luo W, Chen W, Zheng G (2019a) A robust but variable lake expansion on the Tibetan Plateau. Sci Bull 64:1306-1309

Zhang G, Xie H, Kang S, Yi D, Ackley SF (2011) Monitoring lake level changes on the Tibetan Plateau using ICESat altimetry data (2003 - 2009). Remote Sens Environ 115:1733-1742

Zhang G, Yao T, Piao S, Bolch, T, Xie H, Chen D, Gao Y, O’Reilly CM, Shum CK, Yang K, Yi S, Lei Y, Wang W, He Y, Shang K, Yang X, Zhang H (2017a) Extensive and drastically different alpine lake changes on Asia's high plateaus during the past four decades. Geophys Res Lett 44:252-260

Zhang G, Yao T, Xie H, Wang W, Yang W (2015) An inventory of glacial lakes in the Third Pole region and their changes in response to global warming. Glob Planet Change 131:148-157

Zhang G, Yao T, Xie H, Zhang K, Zhu F (2014) Lakes' state and abundance across the Tibetan Plateau. Chin Sci Bull 59:3010-3021

Zhu L, Xie M, Wu Y (2010) Quantitative analysis of lake area variations and the influence factors from 1971 to 2004 in the Nam Co basin of the Tibetan Plateau. Chi Sci Bull 55:1294-1303 


\section{Tables}

Table 1 Annual values for the parameters of the water balance model from 10/1999 to 10/2009. $\mathrm{P}_{\mathrm{L}}$ is the precipitation on the lake surface (Wu et al. 2014). $\mathrm{S}_{\mathrm{L}}$ is the lake surface area (average of the area at the start and end of the time period). $\mathrm{S}_{\mathrm{C}}$ is the area of catchment excluding the lake area. $E_{\mathrm{L}}$ is the evaporation from the lake surface. $\mathrm{LVC}$ is the lake volume change in each period

\begin{tabular}{ccccccr}
\hline start & end & $\mathrm{P}_{\mathrm{L}}(\mathrm{mm})$ & $\mathrm{S}_{\mathrm{L}}\left(\mathrm{m}^{2}\right)$ & $\mathrm{S}_{\mathrm{C}}\left(\mathrm{m}^{2}\right)$ & $\mathrm{E}_{\mathrm{L}}(\mathrm{mm})$ & $\mathrm{LVC}\left(\mathrm{m}^{3}\right)$ \\
\hline $10 / 1999$ & $10 / 2000$ & 199 & 63897313 & 1988402687 & 916 & 27017800 \\
$10 / 2000$ & $10 / 2001$ & 165 & 67175062 & 1985124938 & 979 & 1161000 \\
$10 / 2001$ & $10 / 2002$ & 205 & 68197610 & 1984102390 & 914 & 13097000 \\
$10 / 2002$ & $10 / 2003$ & 149 & 68967180 & 1983332820 & 886 & -10094000 \\
$10 / 2003$ & $10 / 2004$ & 130 & 67938056 & 1984361944 & 997 & -5669000 \\
$10 / 2004$ & $10 / 2005$ & 159 & 66809354 & 1985490647 & 942 & -2652000 \\
$10 / 2005$ & $10 / 2006$ & 166 & 67833813 & 1984466187 & 962 & 21009000 \\
$10 / 2006$ & $10 / 2007$ & 157 & 69168096 & 1983131905 & 984 & 384000 \\
$10 / 2007$ & $10 / 2008$ & 205 & 70129135 & 1982170865 & 975 & 8777000 \\
$10 / 2008$ & $10 / 2009$ & 125 & 70121542 & 1982178458 & 1006 & -14563000 \\
\hline
\end{tabular}

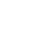

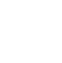


612 Table 2 The results of changing model constants $c$ and $g$ to optimize $r^{2}$, slope and intercept of 613 the relationship between known and modelled $\Delta V_{L}$

\begin{tabular}{ccccc}
\hline Constant $c$ & Constant $g$ & $r^{2}$ & slope & intercept \\
\hline 0.06 & 0.13 & 0.64 & 1.00 & $31,493,754$ \\
0.09 & 0.94 & 0.51 & 0.28 & 15 \\
0.84 & 0.74 & 0.68 & 0.17 & $-38,453,042$ \\
\hline
\end{tabular}

614

615

616

617

618

619

620

621

622

623

624

625

626

627

628

629

630

631

632

633

634

635

636

637 
638 Table 3 Estimates of contributions of different hydrological components of the Aweng Co 639 system from the isotope mass balance calculation (Equation 6)

640

\begin{tabular}{cccc}
\hline & \multicolumn{2}{c}{ Hydrological Component } & \multicolumn{2}{c}{ Contribution (\%) } \\
\cline { 2 - 4 } & & from $\delta^{18} \mathrm{O}$ balance & from $\delta^{2} \mathrm{H}$ balance \\
\hline \multirow{3}{*}{ Water input } & $\mathrm{P}_{\mathrm{L}}$ & 10 & 11 \\
& $\mathrm{R}_{\mathrm{C}}$ & 19 & 20 \\
& $\mathrm{GMW}$ & 4 & 5 \\
\cline { 2 - 4 } & $\mathrm{G}_{\mathrm{I}}$ & 67 & 65 \\
\hline \multirow{2}{*}{ Water output } & $\mathrm{E}$ & 57 & 61 \\
\cline { 2 - 4 } & $\mathrm{G}_{\mathrm{O}}$ & 43 & 39
\end{tabular}

641

642

643

644

645

646

647

648

649

650

651

652

653

654

655

656

657

658

659

660

661

662

663

664

665

666

667

668

669 


\section{Figure captions}

671

Fig.1 The location of Aweng Co (a), the topography of Aweng Co catchment (b) and the monthly mean temperature and total monthly precipitation at Shiquanhe Station (c). The boundary of the inner TP (a) was defined according to Zhang et al. (2015).

675

Fig. 2 Comparisons of lake area change and glacier area change with $\delta^{18} \mathrm{O}_{\text {carb }}$ value, and meteorological data. (a) Interpolated precipitation in the Aweng Co catchment from 1980 to 2012 (Wu et al. 2014). (b) Interpolated mean summer temperature (June to August) in the Aweng Co catchment from 1980 to 2012 (Wu et al. 2014). (c) Calculated evaporation on the lake surface from May to September in the Aweng Co catchment. (d) Aweng Co lake area since 1979. (e) Calculated lake volume. (f) Glacier area change from 1996 to 2010. (g) Sedimentary record $\delta^{18} \mathrm{O}_{\text {carb }}$ from Aweng Co from 1978 to 2014 (The data of $\delta^{18} \mathrm{O}_{\text {carb }}$ are shown in ESM 5). The black dots and bars represent the chronology of the samples and the errors (full data presented in ESM 4).

Fig. 3 The linear correlation between each parameter (left to right: precipitation on the lake surface; evaporation on the lake surface and glacier melt water) and lake volume change. $\mathrm{P}_{\mathrm{L}}$ represents precipitation on the lake surface. $\mathrm{S}_{\mathrm{L}}$ represents lake surface area. $\mathrm{E}_{\mathrm{L}}$ represents evaporation on the lake surface.

Fig. $4 \delta^{18} \mathrm{O}$ vs. $\delta^{2} \mathrm{H}$ of different waters from Aweng Co. Blue dots are lake water from Aweng Co. Green Rhombus is the groundwater from the Aweng Co basin. Light blue crosses are lake water isotopes from the western Tibetan Plateau (Yuan et al. 2011). Small and large dark blue triangles are sampled precipitation and mean precipitation in the Aweng Co region respectively. Yellow triangle is the estimated isotopic value of the air vapour over the lake, black cross is the isotope value of the calculated evaporation from the lake surface, orange square is the calculated regional index lake (see text for details). MWL is the meteoric water line from Ngari station (Guo et al. 2017). Aweng Co MWL is the local meteoric water line. LEL is the local evaporation line. The isotope data used in this study are shown in ESM 5. 
703

704

705

706

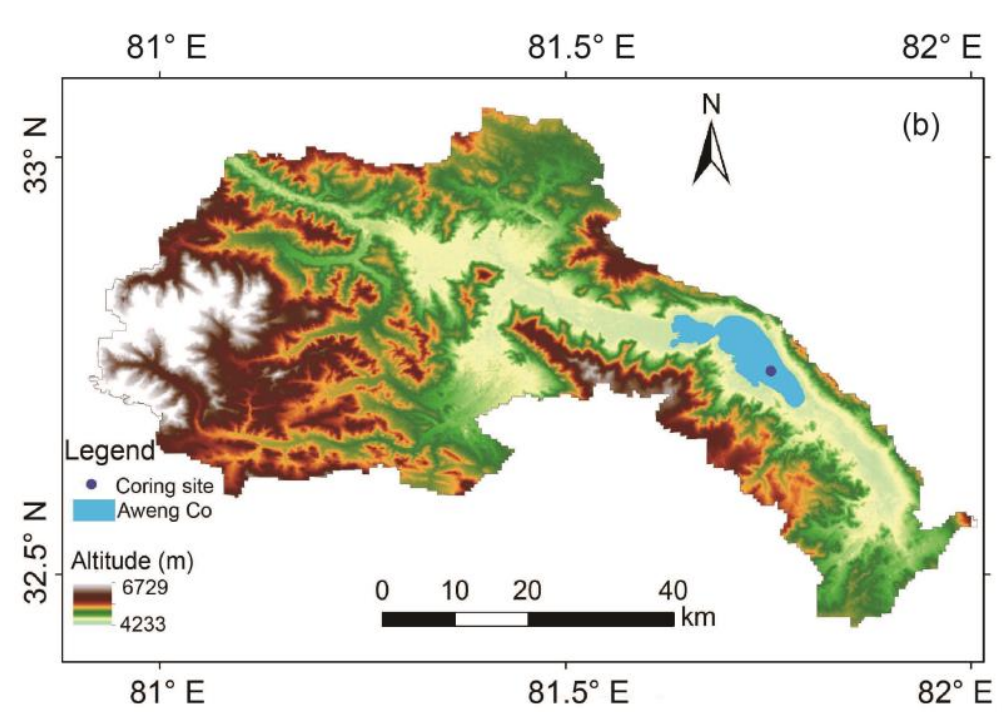

707

Fig. 1

Figures

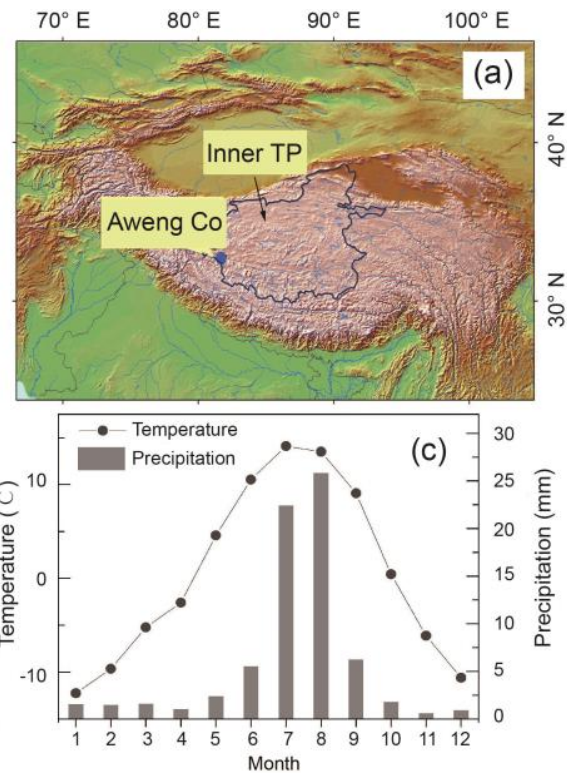

708

709

710

711

712

713

714

715

716

717

718

719

720

721

722

723

724 

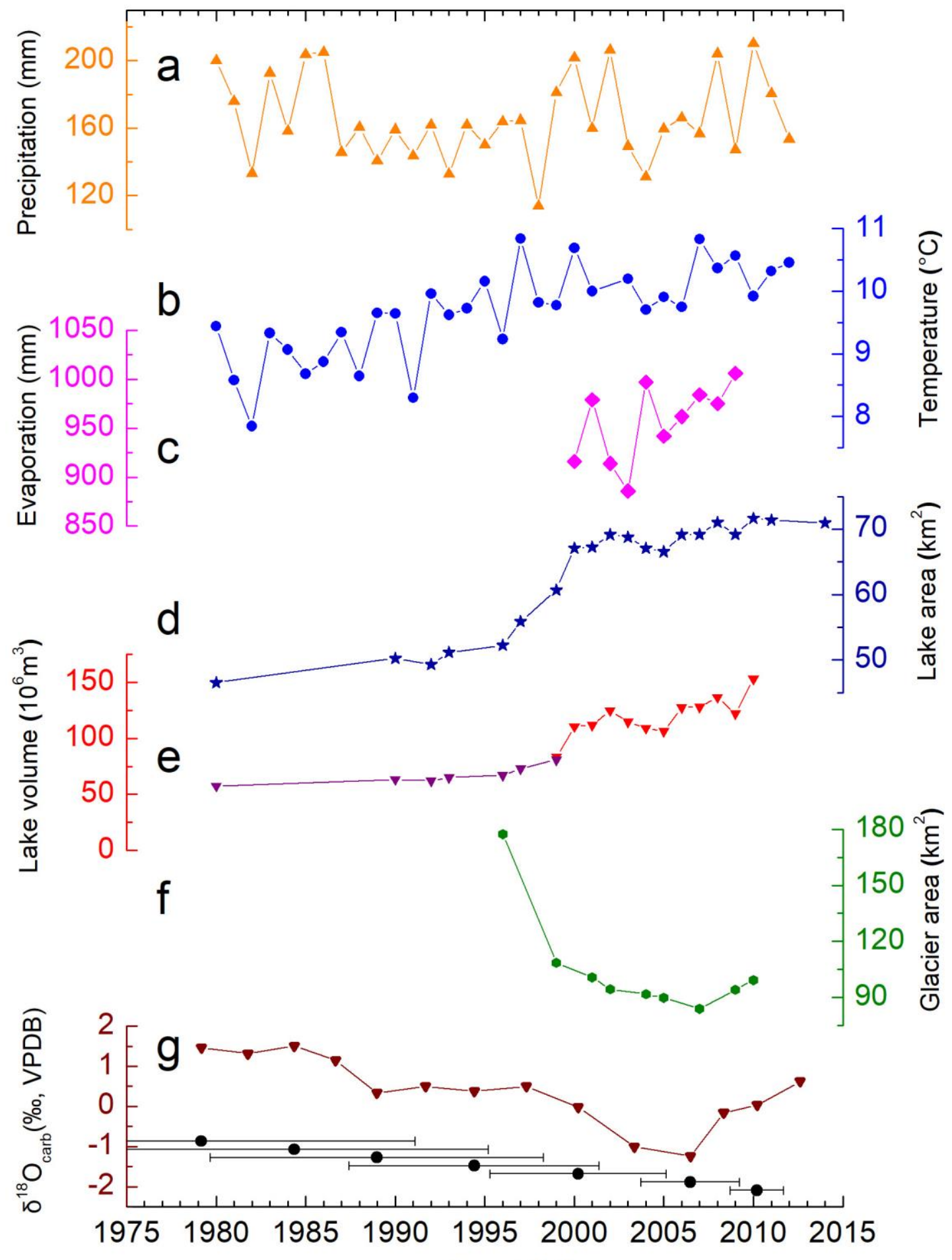

Age (AD) 
Fig. 3

732

733
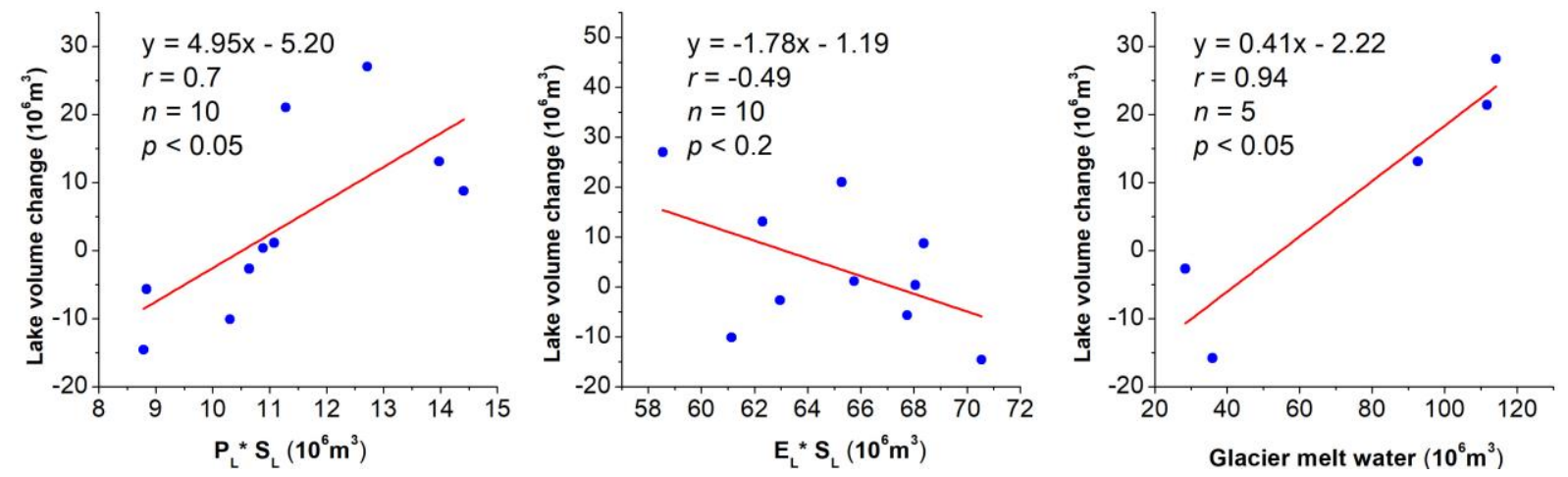

734

735

736

737

738

739

740

741

742

743

744

745

746

747

748

749

750

751

752

753

754

755

756

757

758

759

760

761

762

763

764

765 
Fig. 4

769

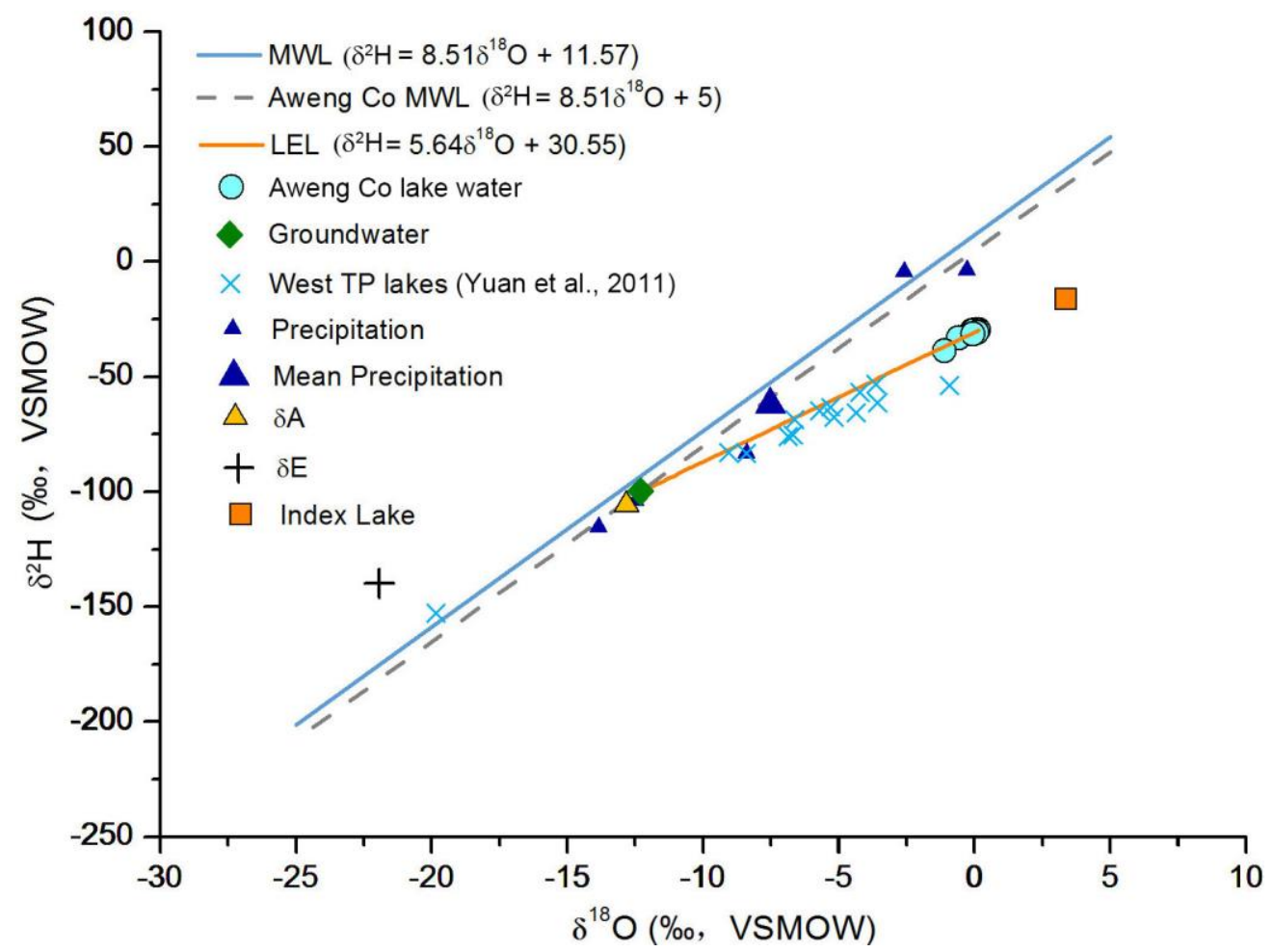

770 